\title{
NESB and ESB students' attitudes and perceptions of plagiarism ${ }^{1}$
}

\author{
Stephen Marshall \\ Victoria University of Wellington, New Zealand \\ Stephen.Marshall@vuw.ac.nz \\ Maryanne Garry \\ Victoria University of Wellington, New Zealand \\ Maryanne.Garry@vuw.ac.nz
}

\begin{abstract}
Concern about plagiarism by students from non-English speaking backgrounds (NESB) has grown apace with the increased numbers of international students attending western institutions. We present an exploration of student attitudes, perceptions and understandings of intellectual property, particularly plagiarism and copyright, and explore potential differences between NESB and ESB (English speaking background) students. The results indicate that while NESB students are more likely have engaged in plagiarism than ESB students, plagiarism overall is very common and reflects a combination of disrespect for material from the Internet and significant confusion about what actually constitutes plagiarism.
\end{abstract}

Keywords: academic integrity, educational integrity, plagiarism, international students, NESB

\section{Introduction}

There hardly seems to be a day now that does not include the report of yet another incidence of plagiarism in either public or academic life. The Internet has seemingly made plagiarism attractive and readily accomplished (Ryan, 1998; McCabe \& Drinan, 1999; Rimer, 2003; Kasprzak \& Nixon, 2004). Of course, the existence of tools like Google has also made detection easier and this may, in part, explain the perception that plagiarism has become more prevalent. However, it remains unclear whether or not the incidence of plagiarism has actually increased (McCabe \& Drinan, 1999; Park, 2003) and whether or not the Internet has contributed (Chester, 2001; Scanlon and Neumann, 2002). One such group to attract particular attention as plagiarists is students from non-English speaking backgrounds (NESB). This may be a consequence of increased international student enrolments in many western institutions, making issues of their capabilities and needs more obvious. It may be that students from some cultures bring with them ideas of information use inconsistent with western academic traditions and norms of behaviour (Pennycook, 1996; Ninnes et al. 1999; Introna et al. 2003; Handa \& Power, 2005), or there may be preconceptions applied by teachers that fail to appreciate the techniques being applied by their students (Watkins and Biggs, 1996; 2001).

Analysing plagiarism by NESB students presents significant challenges as a 'mythology' of information about students from cultures other than our own has developed in the western academic tradition (Biggs, 1999; Desruisseaux, 1999; Handa \& Power, 2005; Leask, 2006). Clearly, while culture is an important aspect of understanding students' backgrounds and experiences prior to study, it is not a rigid determinant of future capability or a predictor of plagiarism per se. Appreciation of

\footnotetext{
${ }^{1}$ This paper is based substantially on a paper presented at the 2nd Asia-Pacific Educational Integrity Conference (Newcastle, 2-3 December 2005) and we acknowledge the feedback of the conference and journal reviewers in the creation of this improved and extended version.
} 
student perceptions and values around information use is necessary if effective strategies for educating a diverse student population are to be developed. Certainly, some instances of plagiarism by NESB students are readily detected due to dramatic changes in language fluency within assessed work, but it is not clear that other, more fluent plagiarists, perhaps from an English speaking background (ESB) are not escaping detection.

Fluency of expression in English is a challenge for many students with some researchers claiming that all students need assistance when developing academic writing skills (Howard, 1995; Wilson, 1997). Not surprisingly, written expression is a particular issue with NESB students (Wan, 2001; Bretag et al. 2002). Evidence suggests that the needs of International and NESB students are not necessarily being well met in developing these skills (Wan, 2001) and that teaching staff need assistance in ensuring that pedagogies and materials are designed for the needs of a diverse range of cultures rather than the dominant Western tradition (Errey, 1994; Pennycook, 1996; Ryan \& Hellmundt, 2003).

As well as the challenges that all students face when undertaking their studies, a number of other contributing factors have been noted as possibly contributing to plagiarism by NESB students:

- Financial pressure to succeed (Introna et al., 2003);

- Lack of support networks from family and friends and a sense of alienation (Introna et al., 2003);

- Cultural norms requiring assisting a friend in need (Cordiero 1995; Walker, 1998);

- Cultural differences in type of understanding required from students - reproductive versus analytical (Burns, 1991; Angelil-Carter, 2000; Handa \& Power, 2005);

- Fear of excessive loss of face and impact on family resulting from poor performance (Burns, 1991; Walker, 1998);

- Differences in moral perception of plagiarism and its significance (Introna et al. 2003);

- English language skills (Bretag et al. 2002; Carroll, 2002, p. 47); and

- Presumption of dominant cultural knowledge in the design and communication of assessment tasks (Mackinnon \& Manathunga, 2003).

These last two explanations may also apply to materials provided to educate students in appropriate information use. The use of unclear or cryptic language is a particular challenge to students studying in a second language, and as well as being a significant problem with assessment task design and communication it also may result in students misunderstanding policies and other documents aimed at reducing plagiarism.

In this paper we present an exploration of NESB students' knowledge and perceptions of plagiarism. This is part of a wider study intended to better appreciate how students understand issues of intellectual property, particularly plagiarism and copyright. An overview of the general results obtained for all students is provided elsewhere (Marshall \& Garry, 2005b).

\section{Methodology}

Many studies of plagiarism by students are undertaken by asking them whether they have engaged in plagiarism or cheating at any stage of their studies. This very broad approach makes it hard to determine the actual extent of plagiarism and is also is less useful in determining what can be done by teachers to discourage it. A single instance of cheating many years previously is hardly a strong indicator of how a student may behave as an adult. It is clear that students get exposed to mixed messages about plagiarism from the real-world and behaviours of institutions and academics (Martin 1994). By examining students' responses to scenarios, and student perceptions of how other students, institutions and the general public regard those situations, it is possible to see patterns of belief that would not be apparent from the more definition-focused instruments.

A particular challenge is to try to deal with the generally recognised problem that survey respondents under-report participation in ethically dubious behaviour such as cheating (Scheers \& Dayton, 1987). Scenarios help by providing more context, as does the use of multiple viewpoints or roles - in essence 
dissociating the respondent from their personal position (Wood et al., 1988; Emerson \& Conroy 2002).

In order to provide a rich set of data to analyze we constructed a survey questionnaire and information sheet (available from the authors on request) which, as well as soliciting basic demographic information, provided students with a variety of possible behaviours that might or might not involve plagiarism so as to test what they actually understood plagiarism to be (Table 1). These presented a variety of behaviours that are potentially plagiarism, as well as clear instances of plagiarism and also acceptable practice.

Decisions about whether or not a particular behaviour was or was not plagiarism was made by the authors applying their institutional definition of plagiarism "Plagiarism is presenting someone else's work as if it were your own, whether you mean to or not" and the associated explanatory documents provided to students. Naturally, this is an exercise of judgment and it is unlikely that all of the identified forms of plagiarism would be seen as such by all academics. The observation that this decision cannot be made mechanistically, along with the debate amongst academics that occurs when making these decisions, is consistent with our contention that understanding the subtleties of plagiarism is challenging for all students.

The students were also provided with fifteen different scenarios (Table 2) that involved issues of copyright and plagiarism. Students were asked to assess how serious the behaviour presented was on a scale from 0 (no issue at all) through to 5 (extremely serious) for themselves. They also were asked to estimate how it might be regarded by other students, the university and the general public. Finally, they were asked to indicate whether and how frequently they had engaged in similar behaviour themselves.

Results were collected anonymously from students enrolled in three different first year courses at a mid-size New Zealand university. A total of 181 responses were collected from 186 students during a class session without the teaching staff present (a 97\% response rate). Of the respondents, 115 identified themselves as ESB and 66 as NESB. Human ethics approval for this research was obtained from the VUW Human Ethics Committee. The statistical significance of differences reported in the text was assessed using the $\mathrm{Chi}^{2}$ test at a 99\% confidence level (results that were very close to this level are also noted in Table 2). Statistically significant differences are noted in Tables 1 and 2. Aspects of this research have been reported elsewhere (Marshall \& Garry, 2005a and 2005b).

Table 1:

Definitions of plagiarism (bold items describe forms of plagiarism)

\begin{tabular}{|l|l|c|c||c|c|}
\hline \multirow{2}{*}{} & \multirow{2}{*}{} & \multicolumn{3}{c|}{ Students Responding Yes } \\
\cline { 3 - 5 } & & \multicolumn{2}{|c|}{ ESB (n = 115) } & \multicolumn{2}{|c|}{ NESB (n = 66) } \\
\hline 1 & $\begin{array}{l}\text { Copying the words from another source without } \\
\text { appropriate reference or acknowledgement }\end{array}$ & 110 & $96 \%$ & $59 \%$ & $89 \%$ \\
\hline 2 & $\begin{array}{l}\text { Copying the words from another source with an } \\
\text { acknowledgement }\end{array}$ & 22 & $19 \%$ & 9 & $14 \%$ \\
\hline 3 & $\begin{array}{l}\text { Resubmitting an assignment that was submitted in one } \\
\text { course for assessment in another course }\end{array}$ & 81 & $70 \%$ & 45 & $68 \%$ \\
\hline 4 & $\begin{array}{l}\text { Creating a new piece of work structured according to a } \\
\text { documentation standard, by referring to existing work } \\
\text { of the same type }\end{array}$ & 12 & $10 \%$ & 10 & $15 \%$ \\
\hline 5 & $\begin{array}{l}\text { Using a published work to identify important } \\
\text { secondary citations that make a particular logical } \\
\text { argument and then citing only those secondary }\end{array}$ & 32 & $28 \%$ & 17 & $26 \%$ \\
\hline
\end{tabular}




\begin{tabular}{|l|l|c|c|c|c|}
\hline & $\begin{array}{l}\text { sources to support your own use of the same logical } \\
\text { argument. }\end{array}$ & & & \\
\hline 6 & $\begin{array}{l}\text { Copying the organisation or structure of another } \\
\text { piece of work without appropriate reference or } \\
\text { acknowledgement }\end{array}$ & 57 & $50 \%$ & $47 *$ & $71 \%$ \\
\hline 7 & $\begin{array}{l}\text { Changing the words of material from another piece } \\
\text { of work and representing it as your own }\end{array}$ & 83 & $72 \%$ & $29 *$ & $43 \%$ \\
\hline 8 & $\begin{array}{l}\text { Buying a complete piece of work in order to submit } \\
\text { it for an assignment }\end{array}$ & 108 & $94 \%$ & $55 *$ & $83 \%$ \\
\hline 9 & $\begin{array}{l}\text { Copying the ideas from another piece of work } \\
\text { without appropriate reference or acknowledgement }\end{array}$ & 88 & $77 \%$ & 48 & $73 \%$ \\
\hline 10 & $\begin{array}{l}\text { Copying a web site and putting your own words } \\
\text { and name into the content part of the pages }\end{array}$ & 106 & $92 \%$ & $44 *$ & $67 \%$ \\
\hline 11 & $\begin{array}{l}\text { Creating a new piece of work on the same theme as an } \\
\text { existing one but in a new context and without copying } \\
\text { the existing one }\end{array}$ & 8 & $7 \%$ & 8 & $12 \%$ \\
\hline 12 & $\begin{array}{l}\text { Using another piece of work to identify useful } \\
\text { secondary citations that you cite in your own work } \\
\text { without reading the cited material. }\end{array}$ & 30 & $26 \%$ & 18 & $27 \%$ \\
\hline 13 & $\begin{array}{l}\text { Quoting from an existing piece of work with a } \\
\text { reference to the source }\end{array}$ & 11 & $10 \%$ & 4 & $6 \%$ \\
\hline 14 & $\begin{array}{l}\text { Copying short sentences (less than 50 words) from } \\
\text { another source without appropriate reference or } \\
\text { acknowledgement }\end{array}$ & 102 & $89 \%$ & $51 *$ & $77 \%$ \\
\hline
\end{tabular}

Results marked with an '*' were found to differ significantly from the ESB results using a $\mathrm{Chi}^{2}$ test of significance at the $99 \%$ level of confidence.

\section{Results}

While some academics may hold that, as with pornography, they know plagiarism when they see it (St. Onge, 1998, p. 51), it is not at all clear that this is true for all students, or even that there is agreement about the range of possible plagiarism types. The student participants were presented with a range of possible plagiarism and cheating behaviours (Table 1) and asked to indicate whether or not they thought these were regarded as plagiarism by the university. Bold items were determined by the authors to constitute plagiarism as noted above; others include a mix of information uses that are not strictly plagiarism.

Examination of these results indicates some disturbing issues. Behaviour that is clearly plagiarism (item 1) is not correctly identified by $4 \%$ of ESB and $11 \%$ of NESB students, while behaviour which is correct (item 13) is thought to be plagiarism by $10 \%$ of ESB and 6\% of NESB students. This suggests that basic understanding of what plagiarism is and is not eludes around $10 \%$ of the students. Of concern, 28\% of ESB and 57\% of NESB students appear to feel that changing the words (item 7) is sufficient to avoid plagiarism, while more subtle forms of plagiarism (e.g. items 5 and 12) appear to be almost unrecognised by the students as forms of plagiarism. NESB students appear to have particular issues with regard to rewriting material from other sources appropriately (item 7) and also with material of an electronic form (item 10), but in general were found to share very similar (mis)understandings of plagiarism as a concept with the ESB students. 


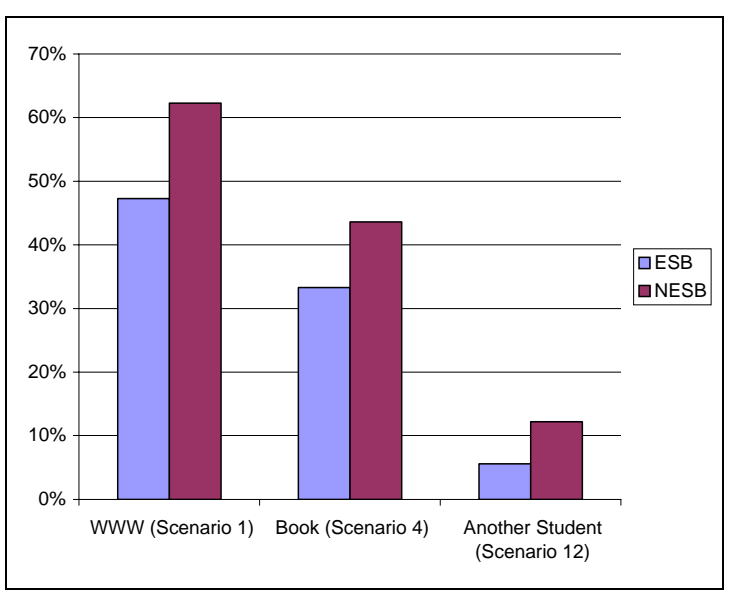

Figure 1: Incidence of different types of plagiarism by ESB and NESB students

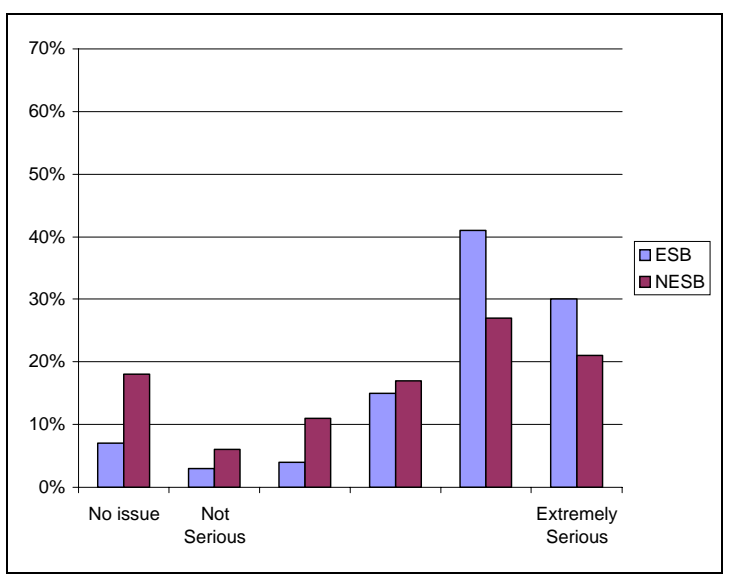

Figure 3: NESB and ESB student attitudes to copying from a book (scenario 4)

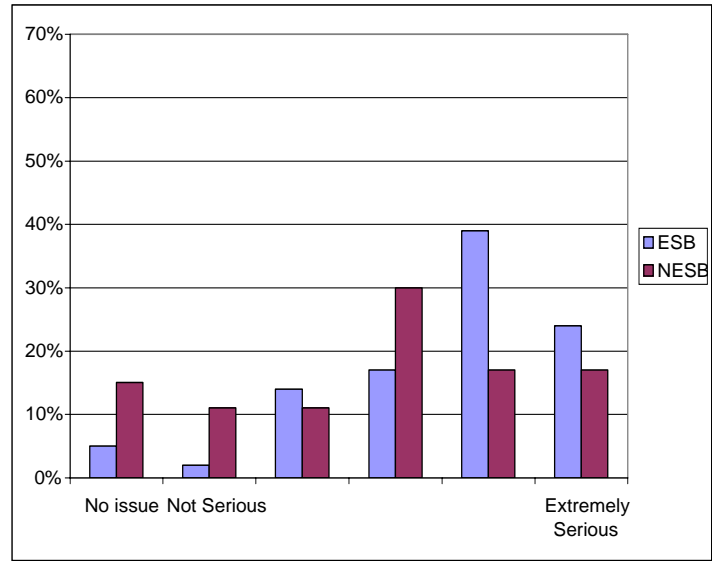

Figure 2: NESB and ESB student attitudes to copying from the web (scenario 1)

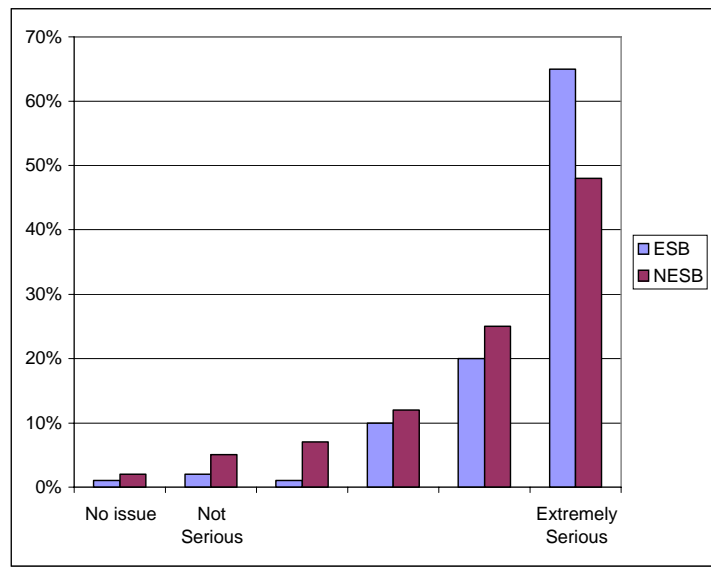

Figure 4: NESB and ESB student attitudes to copying from another student (scenario 12)

With such a large number of students failing to demonstrate even a basic understanding of plagiarism it is clear that simply asking students whether or not they have engaged in plagiarism is unreliable (Dean, 2000; Park, 2003). Instead, students were presented in this study with scenarios describing particular activities that might or might not constitute plagiarism (Table 2). Students were asked to indicate whether they had engaged in essentially the same activity themselves and if they had, how frequently.

Seven of the scenarios in Table 2 describe activities considered plagiarism by the authors and consistent with the definition items listed in Table 1. Bold scenarios in Table 2 were determined by the authors to constitute plagiarism; others include a mix of appropriate and inappropriate information uses that are not strictly plagiarism and/or copyright violations.

Selling an assignment online was the least prevalent (2.5\% of NESB and 4.3\% of ESB students) and copying from web sources the most prevalent (62.3\% of NESB and $47.3 \%$ of ESB students) of activities admitted to by students. Notably, in most cases, and for all of the clear forms of plagiarism, more NESB than ESB students indicated they had engaged in that activity (Figure 1). In regard to the significance of the differences observed, it should be noted that the results for scenarios 4 and 7 were significant at the $90 \%$ level and the trend seen in Figure 1 strongly suggested that increasing the sample sizes would improve the significance of the results. 
Figure 1 also illustrates that students admit to plagiarism from web sources more than books and much less so from other students. This is mirrored in the answers to the questions about how seriously students regard the different forms of direct plagiarism (Figures 2-4). Plagiarism from web sources was considered generally less serious by students than plagiarism from books while plagiarism from other students was regarded as much more serious than other forms of plagiarism.

Table 2:

Scenarios and reported incidence (bold items describe forms of plagiarism)

\begin{tabular}{|c|c|c|c|}
\hline & & ESB & NESB \\
\hline 1 & $\begin{array}{l}\text { A student is working on an assignment that is worth a significant } \\
\text { proportion of the marks for a course. They conduct a web search and } \\
\text { discover several obscure web pages containing useful material. They } \\
\text { copy sections of the material from the different pages directly into } \\
\text { their assignment without citing the source. They then add additional } \\
\text { original material linking the copied material into a whole and submit } \\
\text { the work as entirely their own. }\end{array}$ & $47.3 \%$ & $62.3 \% * *$ \\
\hline 2 & $\begin{array}{l}\text { A student copies the installation CD for a commercial software package } \\
\text { from their employer that is only licensed for use on the business premises. } \\
\text { They then install the software on their home computer so they can use it to } \\
\text { do work that relates to their courses at University. }\end{array}$ & $55.0 \%$ & $55.9 \%$ \\
\hline 3 & $\begin{array}{l}\text { A student submits unchanged their own originally created work, } \\
\text { which they have previously used for another course, for assessment in } \\
\text { yet another course. }\end{array}$ & $25.9 \%$ & $22.0 \%$ \\
\hline 4 & $\begin{array}{l}\text { A student is working on an assignment that is worth a significant } \\
\text { proportion of the marks for a course. While reading a book in the } \\
\text { library they discover a page that contains a useful block of material. } \\
\text { They copy the material into their assignment answer without citing the } \\
\text { source and submit the work as entirely their own. }\end{array}$ & $33.3 \%$ & $43.6 \%$ \\
\hline 5 & $\begin{array}{l}\text { A student copies the installation CD for the latest cool game from a friend } \\
\text { and installs it on their computer in order to play the game. }\end{array}$ & $74.8 \%$ & $77.8 \%$ \\
\hline 6 & $\begin{array}{l}\text { A student who is a fan of a TV series, carefully videotapes each episode } \\
\text { and creates a personal library of the tapes which they share with friends } \\
\text { and retain for their own enjoyment over a number of years. }\end{array}$ & $81.1 \%$ & $68.5 \% *$ \\
\hline 7 & $\begin{array}{l}\text { An employee preparing a report for internal use at their company } \\
\text { discovers a similar report online using a search engine and uses as the } \\
\text { basis of their own report, paraphrasing it and introducing additional } \\
\text { material specific to their own situation. }\end{array}$ & $24.0 \%$ & $34.0 \%$ \\
\hline 8 & $\begin{array}{l}\text { A student submits unchanged their own originally created work, } \\
\text { which they have previously prepared as part of their employment, for } \\
\text { assessment in a course. }\end{array}$ & $19.0 \%$ & $25.5 \%$ \\
\hline 9 & $\begin{array}{l}\text { A student who is a fan of a particular musical group and who owns many } \\
\text { of their CDs borrows an import CD from a friend that is not available for } \\
\text { purchase and burns a copy for their own use. }\end{array}$ & $75.8 \%$ & $72.3 \%$ \\
\hline 10 & $\begin{array}{l}\text { A student and a staff member work together on a particular problem. } \\
\text { Together they work out an interesting solution that includes a significant } \\
\text { contribution from the student. The staff member submits the solution as a } \\
\text { paper without the student's name listed as an author and without any } \\
\text { acknowledgement of the student's contribution. }\end{array}$ & $5.4 \%$ & $14.0 \% *$ \\
\hline 11 & $\begin{array}{l}\text { A student, having received a good mark for a piece of assessed work, } \\
\text { sells the work to an online "paper mill" that they know on-sells the }\end{array}$ & $4.3 \%$ & $2.5 \%$ \\
\hline
\end{tabular}




\begin{tabular}{|l|l|c|c|}
\hline & work to other students. & $5.6 \%$ & $12.2 \%^{* *}$ \\
\hline 12 & $\begin{array}{l}\text { A student is working on an assignment that is worth a significant } \\
\text { proportion of the marks for a course. While studying in the library } \\
\text { they discover a final draft of another student's work for that } \\
\text { assignment. They copy the material into their assignment directly and } \\
\text { submit the work as entirely their own and without any mention of the } \\
\text { other students name. }\end{array}$ & $\begin{array}{l}\text { A student who is a fan of a particular musical group and who owns many } \\
\text { of their CDs converts the contents to computer files which they can then } \\
\text { sort and play in different orders while working at their computer. }\end{array}$ & $78.4 \%$ \\
\hline 14 & $\begin{array}{l}\text { An employee copies the installation CD for a commercial software } \\
\text { package from a friend and installs it on a work computer in order to } \\
\text { complete an important piece of work that will generate considerable } \\
\text { business for the company and likely result in a bonus to them personally. }\end{array}$ & $21.6 \%$ & $21.1 \%$ \\
\hline 15 & $\begin{array}{l}\text { A student uses an existing novel as the basis of a short satirical allegory. } \\
\text { The resulting work acknowledges the origin of the allegory and only } \\
\text { includes short quotes or directly copied material. The student submits the } \\
\text { work for assessment in a course as their own original work. }\end{array}$ & $27.3 \%$ & $25.0 \%$ \\
\hline
\end{tabular}

Results marked with an '*' were found to differ significantly from the ESB results using a $\mathrm{Chi}^{2}$ test of significance at the $99 \%$ level of confidence; results marked with $a^{~ ' * * '}$ were different at the $98 \%$ level of confidence.

Given the lack of understanding of plagiarism noted above it is perhaps not unexpected that such a large number of students indicated they had engaged in activities that constitute plagiarism. When the results for the different scenarios are combined (Table 3) $72 \%$ of all students (65\% of ESB and $83 \%$ of NESB, statistically significant difference at the 99\% level) admitted to having engaged in some form of clear and serious plagiarism at some time. The scenarios which are grouped in Table 3 as serious plagiarism are ones which meet even the most constrained and limited definition possible, direct copying or its facilitation. By contrast, differences between NESB and ESB students were not seen in scenarios covering copyright issues.

Across all of the scenarios, engaging in a particular activity was negatively correlated with the seriousness with which it was regarded. This is consistent with the NESB students regarding most forms of plagiarism as less serious than ESB students, given the relatively higher incidence. It was also noted that ESB students consistently thought that the University regards each plagiarism behaviour as a more serious issue than NESB students do. Difference in incidence and attitudes between NESB and ESB students did not extend to the scenarios covering copyright issues.

Table 3:

Plagiarism incidence

\begin{tabular}{|l|l|l|l|l|}
\hline & \multicolumn{2}{|l|}{$\begin{array}{l}\text { All Types of Plagiarism } \\
\text { (Scenarios 1,3,4,7,8,11,12) }\end{array}$} & \multicolumn{2}{l|}{$\begin{array}{l}\text { Serious Plagiarism } \\
\text { (Scenarios 1,4,11,12) }\end{array}$} \\
\hline ESB (n=115) & 85 & $74 \%$ & 75 & $65 \%$ \\
\hline NESB (n=66) & 57 & $86 \%^{* *}$ & 55 & $83 \%^{*}$ \\
\hline Total (n=182) & 143 & $79 \%$ & 131 & $72 \%$ \\
\hline
\end{tabular}

Results marked with an '*' were found to differ significantly from the ESB results using a $\mathrm{Chi}^{2}$ test of significance at the $99 \%$ level of confidence; results marked with a '**' were different at the $95 \%$ level of confidence. 


\section{Discussion}

Differences in understanding and the extent of plagiarism were observed between NESB and ESB students in this study. The results in Table 3 suggest that NESB students are significantly more likely to have engaged in serious forms of plagiarism (83\%) than ESB students (65\%). Similar results are found consistently across the forms of direct plagiarism (Figure 1). This must, however, be seen in the context of the high level of plagiarism reported overall and the poor level of understanding of plagiarism demonstrated by all students (Table 1). It can be contended that the students (particularly the NESB students) did not understand what they were being asked, particularly with the definition items, but if it is accepted that between 4 and $11 \%$ of students misread "copying the words from another source without appropriate reference or acknowledgement" (item 1) and thus incorrectly thought this is not plagiarism, then what possible hope is there that they can understand the subtleties of a typical plagiarism warning provided by an institution? It is also worth noting that the student understandings of the scenarios and definitions relating to copyright generally showed much greater similarity between the ESB and NESB groups.

It is clear that simply asking students whether or not they have engaged in plagiarism is unreliable (Dean, 2000; Park, 2003). By providing the students with an opportunity to indicate the seriousness of behaviours in context and their sense of how other students regard these activities we have provided them with a way of separating themselves from any misbehaviour. This approach has been used in a variety of ethical behaviour assessments and is considered more reliable than direct questions (Wood et al., 1988; Emerson \& Conroy 2002). As reported by others (Park, 2003), students, particularly NESB students, do not seem to regard most forms of plagiarism as a particularly serious problem. The differences observed in the results for scenario 1 (Figure 2) and scenario 12 (Figure 4) illustrate this clearly.

Plagiarising from web sources was the most common form admitted to by all students, consistent with other reports (Scanlon \& Neumann, 2002), and this suggests that increased access to the Internet has likely increased the incidence of plagiarism. Gajadhar (1998) has described students as regarding web materials as "free for anyone to use" and students clearly regard digital information as less valuable than other forms (Baruchson-Arbib \& Yaari, 2004) and are disposed to simply using it without reference or in violation of the law (Lenhart et al., 2000).

Clearly there is a need to convey to all of the students more effectively what is meant by plagiarism and how to avoid it. Students need guidance in understanding plagiarism in terms other than moral outrage. It has been observed (Marshall \& Garry, 2005b) that the students regarded all of these scenario behaviours as less serious themselves than they thought the university would, suggesting that students regard the institution as authoritarian. Institutions need to move on from instilling fear and shoulder the responsibility to use forms of assessment that cannot be easily plagiarised (Carroll, 2002) and which demonstrate the regard with which we hold the experiences and ideas of students from other countries and cultures (Briggs, 2003; Leask, 2006). If students are exposed to opportunities to misuse information and become normalised to forms of plagiarism such as copying from the web, they are more likely to minimise the seriousness of such actions (Longenecker et al., 2001). The strong negative correlation between engaging in an activity and its seriousness observed in the current study indicates that effective use of information needs to be addressed as early as possible if students are to be motivated to avoid plagiarism and rationalizations of it after the fact.

It has been suggested that NESB students appear to approach courses with a much stronger focus on meeting minimum requirements or standards without necessarily considering other factors that they regard as less important (Ninnes et al. 1999; Kember, 2000; Lahur, 2004). It is certainly clear that a lack of fluency with the primary language of administration and teaching is a serious handicap that will inhibit participation and achievement, particularly in less structured activities (Volet, 2003) and this is likely to be an issue for NESB students irrespective of the cultural background (Biggs, 1999; Watkins \& Biggs, 1996; Lahur, 2004; Leask, 2006). Achieving fluency is not an easy task and it is thus unsurprising that there is evidence of students adopting coping strategies in order to meet the assessment expectations of courses. The sense conveyed by the excuses used ("I thought we only have 
to change the keywords”, Lahur, 2004) as well as the responses in the current work (for example, items 7 and 14 in table 1) is that NESB students are looking for a simplifying rule that they can apply when using information from other sources. Treating such strategies as plagiarism is clearly at odds with the techniques used to teach students English writing, many of which use mechanistic approaches such as standardised paragraphs and structured writing (Gomez et al., 1996). The intention is that such strategies are stepping stones to more nuanced understandings of information use and fluency in English and academic writing, but it is clear that this is taking longer to develop in the cohort of students studied than might be desired.

Despite the clear role that language skills play, it is necessary to go beyond this examination of the student to consider "[h]ow teachers can encourage students to engage in appropriate learning activities” (Biggs \& Watkins, 2001). All students would benefit from an improved understanding of how to engage in academic writing and ethical use of information from multiple sources. International and NESB students often report that they find assessment tasks confusing and unclear (Ryan \& Hellmundt, 2003) perhaps reflecting the use of cryptic language or implicit questions in assessment tasks (Errey, 1994). Clarity of objectives and expectations would be of benefit to all students. Beyond this, there is also the responsibility of teachers and institutions to understand and reflect in their courses an appreciation of the positive role that NESB and international students can play in creating an effective learning environment for all students (Volet, 2003; Leask, 2006). This will be challenging while deficit models of NESB learners remain prevalent (Chalmers \& Volet, 1997), despite the evidence that differences are not necessarily weaknesses (Pennycook, 1996; Watkins \& Biggs, 1996; Biggs, 1999; Kember, 2000).

\section{Conclusion}

This study is clearly only a beginning and it is intended to continue to gather data in this fashion as other initiatives to improve policy, communication strategies and assessment practices are undertaken. By establishing a baseline, we can measure the impact these initiatives are having while also avoiding an unnecessary focus on NESB students as a particular group. A starting point for addressing the challenges raised by this data must be clarity in definitions of plagiarism (Carroll, 2002). This may present some difficulty as academic disciplines have significantly different understandings of plagiarism (Walker, 1998). In the current work, students consistently reported that they thought the university regarded plagiarism as a more serious issue than they did themselves. This suggests that strategies for reducing plagiarism that depend on deterrence are likely to be less effective than strategies aimed at improving the design of assessment and demonstrating the values we hold as academics and teachers when using information from all sources (Crown \& Spiller, 1998).

Stephen Marshall is a Senior Lecturer in Educational Technology at the VUW University Teaching Development Centre. Stephen is a member of the New Zealand Ministry of Education Tertiary ELearning Reference Group and researches in the areas of plagiarism and academic integrity, intellectual property and the development of policy and strategy to support and encourage the effective use of technology.

Maryanne Garry is a Reader in Psychology at Victoria University of Wellington in New Zealand. She received her PhD in 1993 from the University of Connecticut, and did postdoctoral research at the University of Washington under the direction of Professor Elizabeth Loftus, the world's foremost researcher on human memory distortions. Her research on human memory distortions has appeared in various international journals and books and she has been an expert witness in several countries, commenting on the reliability of human memory in criminal trials. 


\section{References}

Angelil-Carter, S. (2000). Understanding plagiarism differently. In Leibowitz, B. and Mohammed, Y. (Eds), Routes to Writing in Southern Africa. Silk Road International Publishers, Cape Town, SA.

Baruchson-Arbib, S. \& Yaari, E. (2004). Printed versus Internet plagiarism: A study of students' perception. International Journal of Information Ethics. 1, 1-7.

Biggs, J. 1999. Teaching international students. In J. Biggs (Ed), Teaching for quality learning at university. What the student does. Buckingham: Open University Press, pp. 121-140.

Biggs, J.B. \& Watkins, D.A. (2001). Insights into teaching the Chinese learner. In D.A. Watkins \& J.B. Biggs (Eds.). Teaching the Chinese learner: Psychological and pedagogical perspectives. Hong Kong: Centre for Comparative Research in Education/Camberwell, Victoria: Australian Council for Educational Research, pp. 277-300.

Bretag, T., Horrocks, S. \& Smith, J. (2002) Developing classroom practices to support NESB students in information systems courses: Some preliminary findings. International Education Journal 3(4), 57-69.

Briggs, R. (2003) Shameless! Australian Universities Review. 46 (1), 19-23.

Burns, R.B. (1991) Study and stress among first year overseas students in an Australian university. Higher Education Research and Development 10(1), 61-77.

Carroll, J. (2002). A handbook for deterring plagiarism in higher education. Oxford Centre for Staff and Learning Development, Oxford Brookes University, Oxford, UK.

Chalmers, D. \& Volet, S. (1997). Common misperceptions about students from South-East Asia studying in Australia. Higher Education Research \& Development, 16(1), 87-98.

Chester, G. (2001). Plagiarism detection and prevention: Final report of the JISC electronic plagiarism detection project. Retrieved August 82004 from http://www.jisc.ac.uk/pub01/plagiarism_final.pdf.

Cordiero, W.P. (1995). Should a school of business change its ethics to conform to the cultural diversity of students? Journal of Education for Business Sept-Oct, 27-29 (cited in Walker, 1998).

Crown, D. F., \& Spiller, M. S. (1998). Learning from the literature on collegiate cheating: A review of empirical research. Journal of Business Ethics 17, 683-700.

Dean, G.R. (2000). Academic dishonesty and the community college. ERIC Digest ED447840.

Desruisseaux, P. (1999). Cheating is reaching epidemic proportions worldwide, researchers say. The Chronicle of Higher Education, 45, A45.

Deshpande, S. P. (1997). Managers' perception of proper ethical conduct: The effect of sex, age and level of education. Journal of Business Ethics 16, 79-85.

Emerson, T.L.N., \& Conroy, S.J. (2004). Have ethical attitudes changed? An intertemporal comparison of the ethical perceptions of college students in 1985 and 2001. Journal of Business Ethics 50, 167-176.

Errey, L. (1994). Cultural diversity: Or who's who in the university?. In C. Rust \& J. Pye (Eds.), Diversity Challenge: How to Support the Learning of an Increasingly Diverse Student Body (pp. 6-12). Oxford: Oxford Brookes University.

Gajadhar, J. (1998). Issues in plagiarism for the new millennium: An assessment odyssey. Retrieved July 192005 from http://ultibase.rmit.edu.au/Articles/dec98/gajad1.htm.

Gomez, R., Parker, R., Lara-Alecio, R. \& Gomez, L. (1996). Process versus product writing with limited English proficient students. The Bilingual Research Journal Spring 1996, 20 (2), 209-233.

Handa, N. \& Power, C. (2005). Land and discover! A case study investigating the cultural context of plagiarism. Journal of University Teaching and Learning Practice. 2(3), 64-84.

Howard, R.M. (1995). Plagiarisms, authorships and the academic death penalty. College English 57(7), 788-806.

Introna, L., Hayes, N., Blair, L. \& Wood, E. (2003). Cultural attitudes towards plagiarism: Developing a better understanding of the needs of students from diverse backgrounds relating to issues of plagiarism. Lancaster University, UK. 
Kasprzak, J., \& Nixon, M. (2004). Cheating in cyberspace: Maintaining quality in online education. Association for the Advancement of Computing In Education, 12(1), 85-99.

Kember, D. (2000). Misconceptions about the learning approaches, motivation and study practices of Asian students. Higher Education 40, 99-121.

Lahur, A.M. (2004). Plagiarism among Asian students at an Australian university offshore campus: Is it a cultural issue? A pilot study. In Proceedings of the HERDSA Conference 2004, Miri, Sarawack, Malysia, Non-refereed paper. Retrieved July 192005 from http://herdsa2004.curtin.edu.my/contributions/NRPapers/A033-jt.pdf .

Leask, B. (2006). Plagiarism, cultural diversity and metaphor - implications for academic staff development. Assessment \& Evaluation in Higher Education, 31(2), 183-199.

Lenhart, A., Fox, S., Rainie, L., Horrigan, J., Spooner, T., Packel, D. \& Burke, M. (2000). Downloading free music: Internet music lovers don't think it’s stealing. Pew Internet \& American Life Project's Online Music Report. Retrieved August 92004 from http://www.pewinternet.org/.

Longenecker, J.G., McKinney, J.A. Moore, C.W. \& Weeks, W.A. (2001). An Empirical Study of the Relationship Between Past Experiences and How Individuals Perceive Ethical Dilemmas. Hawaii Conference on Business, Hawaii, 2001. Retrieved August 82004 from http://business.baylor.edu/web/DEPT/COMM\&MKT/Ethics2.doc.

MacKinnon, D. \& Manathunga, C. (2003). Going global with assessment: What to do when the dominant culture's literacy drives assessment. Higher Education Research and Development 22(2), 131-144.

Marshall, S. \& Garry, M. (2005a). NESB and ESB students' attitudes and perceptions of plagiarism. Paper presented at the 2nd Asia-Pacific Educational Integrity Conference, Newcastle, Australia (2-3 December, 2005).

Marshall, S. \& Garry, M. (2005b). How well do students really understand plagiarism? In Goss, H. (Ed.), Proceedings of the $22^{\text {nd }}$ annual conference of the Australasian Society for Computers in Learning in Tertiary Education (ASCILITE) (pp. 457-467). Brisbane, Australia, 4-7 ${ }^{\text {th }}$ December.

Martin, B. (1994). Plagiarism: A misplaced emphasis. Journal of Information Ethics 3(2), 36-47.

McCabe, D.L. \& Drinan, P. (1999). Toward a culture of academic integrity. The Chronicle of Higher Education. Oct 15, 1999, 46, 8.

Ninnes, P., Aitchison, C. \& Kalos, S. (1999). Challenges to stereotypes of international students' prior educational experience: Undergraduate education in India. Higher Education Research \& Development, 18(3), 323-342.

Park, C. (2003). In other (people’s) words: Plagiarism by university students - literature and lessons. Assessment and Evaluation in Higher Education 28(5), 471-488.

Pennycook, A. (1996). Borrowing others' words: Text, ownership, memory, and plagiarism. TESOL Quarterly 30(2), 201-230.

Rimer, S. (2003). A campus fad that’s being copied: Internet plagiarism. The New York Times. September 3, 2003.

Ryan, J.J.C.H. (1998). Student plagiarism in an online world. ASEE Prism Magazine. December 1998.

Ryan, J. \& Hellmundt, S. (2003). Excellence through diversity: Internationalisation of curriculum and pedagogy. Paper presented at the 17th IDP Australian International Education Conference.

Retrieved August 92004 from http://www.idp.com/17aiec/selectedpapers/Ryan\%20\%20Excellence\%20through\%20diversity\%2024-10-03.pdf.

St. Onge, K.R. (1988). The melancholy anatomy of plagiarism. University Press of America, Lanham, MD, USA.

Scanlon, P.M. \& Neumann, D.R. (2002). Internet plagiarism among college students. Journal of College Student Development 43(3), 374-385.

Scheers, N.J. \& Dayton, C.M. (1987). Improved estimation of academic cheating using randomised response techniques. Research in Higher Education 26(1), 61-69.

Straw, D. (2002). The plagiarism of generation 'why not?'. Community College Week 14(24), 4-7.

Volet, S. (2003). Challenges of internationalisation: Enhancing intercultural competence and skills for critical reflection on the situated and non-neutral nature of knowledge. Keynote Address presented at the Language and Academic Skills in Higher Education National Conference, 
Adelaide, November. Retrieved March 62006 from http://www.flinders.edu.au/SLC/Volet.pdf.

Walker, J. (1998). Student plagiarism in universities: What are we doing about it? Higher Education Research and Development 17(1), 89-106.

Wan, G. (2001). The learning experiences of Chinese students in American universities: A cross cultural perspective. College Student Journal 35(1), 28-45.

Watkins, D. A. \& Biggs, J. B. (1996). The Chinese learner: Cultural, psychological and contextual influences. Hong Kong: Centre for Comparative Research in Education/Camberwell, Victoria: Australian Council for Educational Research.

Watkins, D.A. \& Biggs, J.B. (2001). Teaching the Chinese learner: Psychological and pedagogical perspectives. Hong Kong: Centre for Comparative Research in Education/Camberwell, Victoria: Australian Council for Educational Research.

Wilson, K. (1997). Wording it up: Plagiarism and the interdiscourse of international students. Paper presented at the HERDSA conference, 8-11 July 1997, Adelaide, Australia.

Wood, J., Longenecker, J., McKinney, J. \& Moore, C. (1988) Ethical attitudes of students and business professionals: A study of moral reasoning. Journal of Business Ethics 7, 249-257. 